\title{
Policy Model Corporate Social Responsibility during the Covid-19 Pandemic: (Empirical Finding of State Own Enterprises in North Sumatra Province, Indonesia)
}

\author{
$\underline{\text { Azizul Kholis }}{ }^{1}$, Lukitaningsih ${ }^{2}$, Sulaiman Lubis ${ }^{3}$ \\ 1,2,3Universitas Negeri Medan, Indonesia \\ Email: azizulkholis@unimed.ac.id
}

\section{Abstract:}

This study aims to examine the company's Corporate Social Responsibility (CSR) fund management policy model, namely both internal factors and external factors. The test was carried out on State Owned Enterprise in North Sumatra Province, Indonesia during the Covid 19 pandemic so that it could be seen what CSR policies were taken by companies in helping the government funding with the Covid 19 pandemic in Indonesian. The sample are 48 state-owned enterprise in this province. The data collection technique is distributing questionnaires through google form, email and other social media. Based on stakeholder theory and corporate social responsibility concept, two variables that influence the company's CSR policies are tested, namely Internal factors with indicators of planning strategies and human corporate culture while External factors support government and public pressure. The novelty of this research is disaster contingency as part of variable Which have effect to CSR Policy. Its means disaster contingency can become important thing to support CSR policy. The results of hypothesis testing with multiple regression indicate that CSR policies are significantly influenced by both internal and external variables. The limitation of the study is that the sample is only one province with small amount of sample and is recommended for a wider research area. The implication of the research is that the government should issue regulations to regulate CSR activities, especially those oriented to handling Covid 19 so that CSR can be more useful.

Keywords:

policy; CSR, disaster; internal, external

\section{Introduction}

CSR policy is very important to implementation because according to Mapfre (2018) its definition of social responsibility as a "voluntary and strategic commitment that entails trying to achieve business targets while complying strictly with its legal and contractual obligations, applying criteria of equity and stability to relationships with its stakeholders, thus contributing to meeting the current and future needs of society. Rumambi (2018) state that company's CSR policy is very important to to implementation in various implementation activities. Ambani (2018) said CSR policies in the field of disasters can be carried out by companies. Susanto (2007) explains that 375 companies in Jakarta show that 209 or $55.75 \%$ of CSR is in the form of various funding, religion (50 companies), internal families (116 companies), social institutions (39 companies), and communities (4 companies) and 166 or $44.25 \%$ of companies stated that there was no CSR program. Azizul, Nasirwan, and Ramdhansyah (2017) regarding the CSR program of domestic Investment Companies has not been implemented optimally due to the company's internal factors even though it is very potential in North Sumatra Province. To optimize the potential for CSR in the province of 


\section{Economit Journal: Scientific Journal of Accountancy, Management and Finance ISSN: 2775-5827 (Online), 2775-5819 (Print)}

Vol. 1, No. 3, August 2021, Page: 177-189

Email: economitjournal@gmail.com

North Sumatra, it is necessary to know what factors actually encourage companies to make CSR policies that can be implemented so that they can become a model for making CSR funding assistance decisions for local governments. The condition of the Covid 19 Pandemic as a social disaster, and the limited local government budget to handle disaster, so it is necessary to develop a CSR fund management policy model by the Company which analyzing the important factors that affect the company's CSR policy, both internal and external variabel. One of the roles of CSR is to help fund disasters, especially in the current Covid-19 pandemic. The World Health Organization (WHO) officially declared Covid-19 a global pandemic on March 11, 2020 (Switzerland, 2011). Then the Indonesian goverment also declared the pandemic to be a national disaster by issuing Government Regulation at. 21 of 2020. Law of the Republic of Indonesia number 24 of 2007 concerning Disaster Management regulates the level of disaster problems in stages. The results of the research by the National Disaster Management Agency (2012) illustrate that the constraints in disaster management are due to the limited budget. Syahrial and Ayub (2019), the number of fatalities was due to logistical shortages. Specifically for the handling of Covid-19, the North Sumatra Provincial local Government reserves the costs for medical and non-medical aspects of the 2020 North Sumatra regional budget refocus. As shown in Table 1 (one) below:

Table 1. North Sumatra Province Government Funded for Covid-19

\begin{tabular}{rll}
\hline \multicolumn{1}{c}{ Implementing Agency } & Number of & \multicolumn{1}{c}{ Information } \\
\hline Regional Disaster Management Agency & IDR. 32 billion & non-medical \\
Provincial Goverment Health office & IDR. 199 Billion & medical \\
Total & IDR. 231 Billion & \\
\hline
\end{tabular}

Source: Information and communication Division of, North Sumatra 2020

Ismael (2020) detailed that the stages of using the budget were a total of IDR 270 billion. Plus, food assistance of around IDR 30 billion, so the total amount is IDR. 300 billion. According to Azizul (2020), limited funds for disaster management can be overcome from company CSR funds, such as maximum utilization of SOE or local SOE CSR funds. The potential of corporate CSR funds in North Sumatra Province is very potential with the number above 55 companies. The potential to reach IDR 500 billion annually. The development of fund management for CSR activities in Indonesia is very good, but there are still a small number of companies running the program.

\subsection{Research Gap and Aim of the Study}

Kalyar (2012) explains that the internal drivers of CSR policies are corporate strategy and corporate culture. According to Siegel (2006) the implementation of CSR is also influenced by external factors such as government support and community pressure. Research conducted by Amran and Devi in the implementation of CSR in Malaysia, (2008) many factors determine the company's internal and external factors. One of them is dependence on the government. If you read the findings of Henrique and Sadostky (1999) on 750 companies in Canada, external factors are closely related to stakeholders. Research conducted by Azizul, Ade and Azhar (2014) explains that CSR programs are influenced by internal and external factors of the company. 
Regarding disasters, referring to Syahrial Ayub, et al (2019) which was carried out after the disaster, stated that the number of fatalities in a disaster that occurred was one of them due to a lack of budget. In addition, the problem of implementing the CSR budget management model of SOEs for optimizing disaster management is very necessary to be investigated, because with this research, a policy model for managing CSR funds for SOE companies can be made to be more coordinated effectively, on target, not overlapping, efficient in use and be optimized. For this reason, this study will examine internal and external factors that influence the company's CSR policies which include aspects of government regulation, public pressure, corporate strategy, corporate human culture and also disaster contingency factors, as a combination of Kalyar (2012), Siegel (2006) and Ambani (2018) models.

The novelty of this research is the disaster contingency factor which is considered as an external factor in strengthening CSR policies. This study will combine all internal factors and external factors that have not been tested with contingency situations, namely the existence of a disaster problem in this case what is meant is the Covid 19 pandemic. tested by several previous researchers. So the main aim of this study to examine the company's Corporate Social Responsibility (CSR) fund management policy model, namely both internal and external factors based on Kalyar (2012), Siegel (2006) and Ambani (2018).

\section{Review of Literatures}

\subsection{Stakeholder Theory}

Stakeholder theory is explained by Freeman and Philips (2002) for parties who are directly or indirectly involved in influencing an entity. This theory explains that for the purpose of sustainability and going concern the organization/entity requires stakeholder involvement as an external factor for the company so that business goals can be achieved. Freeman and Philips (2002) also stated tahd Stakeholder theory is a basic consept and grand theory for CSR Model. CSR is a corporate social responsibility which is a mission carried out by carrying out three main missions, namely economic, environmental and social. Definition of CSR in the International Finance Corporation (IFC), 2000: "A business commitment to sustainable economic development through partnerships. Azizul (2018) revealed that CSR is part of the company's social performance. CSR policy can be a company strategy in building business competition. This policy is important and must be put forward by the company.

\subsection{Indonesia's CSR Policy}

Some of Indonesia's most important CSR regulations are the Decree of the Minister of SOEs unader number 05/MBU/2007 concerning the Community Development Partnership Program In detail, it can be seen in table 2 below:

Table 2. CSR Regulations Act in Indonesia

\begin{tabular}{lll}
\hline \multicolumn{1}{c}{ Regulation } & Year & Remarks \\
\hline Limited Liability Company Law Number 40 of 2007 & 2007 & article 74 \\
Law on Foreign Investment in Indonesia Number 25 of 2007. & 2007 & $\begin{array}{l}\text { Article 15 (b) } \\
\text { and article 34 }\end{array}$ \\
of the Law on companies in the field of Oil and Gas Number 22 of & 2001 & Article 13
\end{tabular}


of Law Number 13 of 2011 concerning the Handling of the Poor, neglected children for welfare

Ministerer of SOEs Per-05/MBU/2007

Development Partnership Program

Government Regulation (PP) Number 47 of 2012 which regulates Social and Environmental Responsibility

Regulation of the Minister of Social Affairs of the Republic of Indonesia Number 13 of 2012 concerning Forum for the responsibility of the business world in the implementation of Social Welfare.
Source:_www.rahmatullah.net, 2020

\subsection{Antecedent Factors for CSR Policy Implementations}

a. Internal Factors: Strategic Planning

Formally, corporate strategy becomes an important part of the organization's role (Andersen, 2000). Carroll (1999) and Frederick (1994) also explain that a strategy with good and systematic planning supports the implementation of CSR that is actualized by the company. Meanwhile (Slater et al., 2006) further describes the importance of internal and external factors related to the environment that are directly related to corporate CSR. This is in line with the environmental uncertainty that must be anticipated by the Company (Isabella and Waddock, 1994). Thus it can be concluded that the company's strategy plays an important role in the implementation of CSR as one of the internal factors.

\section{b. Internal Factors: Corporate Humanities Culture}

Siegel's (2006) Generally describes that human culture is a good value that exists in a company so that it can be one of the indicators. This can reflect a good company, disrupted organization, healthy or not. Of course, a company must pay attention to the existence of value as the main aspect because it is very important. However, the activity of carrying out and giving birth to these corporate cultural values to all human resources in the company's organization is relatively not easy. A cultural value must be a behavior, part of work, integrity, habit, and even become a corporate culture commitment in achieving the goals. According Kristesson, Beng, et.al (2012), only the humanities can put the global economy back on Track and Then Heilman (2012), the human factor occupies a pivotal role, as man has become a being that relates to and assumes responsibility for a number of 'external' factors: be it the surrounding environment, objects, extensions of himself or other human beings.

\section{c. External Factors: Government Support}

Government support is very important because of the lack of government support in the form of regulations to encourage companies to implement CSR. Moreover, for the context in Indonesia, government regulations and support are made in a layered legal umbrella starting from government regulations, to regional regulations. This is proof that government support in the form of regulation is needed. Social regulation (eg norms), co-regulation and the market. Azizul, Ade Fatma's and Azhar Maksum (2018), state Government support to CSR is a positive and significan to Corporate social Performance. P Adamek (2013) describe that the role of CSR in government policy have relevance to a particular CSR sector.Understanding the potential of role of government policy is important to the design of regulation. At one level it interfaces with ideas of self-regulation and co-regulation, and at another it challenges the basis of the modern liberal market economy. 


\section{d. External Factors: Communities Pressure}

Oe \& Yamaoka (2020) discussed how to enhance sustainability goals implementation in business behaviour, with a focus on relationships and partnerships with community and other social stakeholders. Azizul, Ade Fatma's and Azhar Maksum (2018) explains that there is a relationship between community pressure to the company's CSR policies, this is because companies must pay attention to the environment around it and existing communities. Fandy (2003) said that community pressure is a development process in which the community takes the initiative to start the process of social activities to improve their own situation and condition. Community pressure can only happen if its citizens participate. P Adamek (2013) the contemporary CSR agenda is founded on the premise that businesses are part of society, their relationship with society is interdependent, and they have the potential to make a positive contribution to societal goals and aspirations.

\section{e. CSR Policy: Top Management Support}

Takemoto et al. (2021) also discussed that relationships within firms is critical with a clear top management message in supporting business sustainability. The idea that top managers can be drivers for corporate social responsibility came from the business sector itself. Specifically, the roots to this literature can be traced to the 1950s when corporate leaders in the United States, followed by academics at pedigreed universities, called for business to act as a trustee of social wellbeing. According to Frederick (2006), one of the first such calls came in 1951 from Frank Abrams (Abrams, 1951), chairman of the board of directors of Standard Oil of Jersey and the author of a seminal statement about the duties executives have to society. Later, in 1971, the Committee for Economic Development (CED, 1971), composed mainly of top-level corporate executives, encouraged business to adopt a broader more humane view of its function in society. The fact that Joseph Wharton founded the first business school in the states as a vehicle for social enterprise knowledge reflected these early calls for business responsibility. Hence, the popularly-held myth in some circles that corporate social responsibility advocates and business representatives are in opposing camps is not well founded, given that business practitioners helped shape ideas about the social role of business. Furthermore, in many cases corporations have adopted tenets of social responsibility as standard practices for responding to public interests (Carroll \& Buchholtz, 2006; Frederick, 2006). When they do, top managers are pivotal to the process.

\section{f. CSR policy: Disaster Contingency}

Theory Contingency explains that the dependence between one variable and objective conditions causes policy and decision making to be in accordance with these conditions. The contingency flexibility of this theory is applied in various fields including disaster. According to Webex, (2020) contingency theory is in line with the accuracy of the goals of an organization and can be used when dynamic changes occur. According to Marvin and Delaine (2012) the theoretical aspects of disaster and stakeholder linkages, one of the environmental causes is the Covid-19 disaster as part of a health disaster. Conceptual Framework for Disasters. CSR.

\section{g. Development of Hypotheses and Analytical Model}

Study by Azhar Maksum (2003), on the variables of community pressure (Community Pressure) and government regulation variables (Government Regulation), empirically proven to have a very significant relationship. Both variables are external factors. Stephenson (2004) tested a factor of environmental information (environmental information) sebagai one internal factor. Hackston \& Milne (1999), Retno (2006) CSR objectives on consumers will have an impact on other external factors and are expected to provide information on social 
responsibility so as to improve the company's image. Based on the above framework, the hypotheses of this research are:

\section{H1: Internal factors have a positive effect on CSR policies}

H2: External factors have a positive effect on CSR policies

The conceptual framework of the research model can be described as follows:

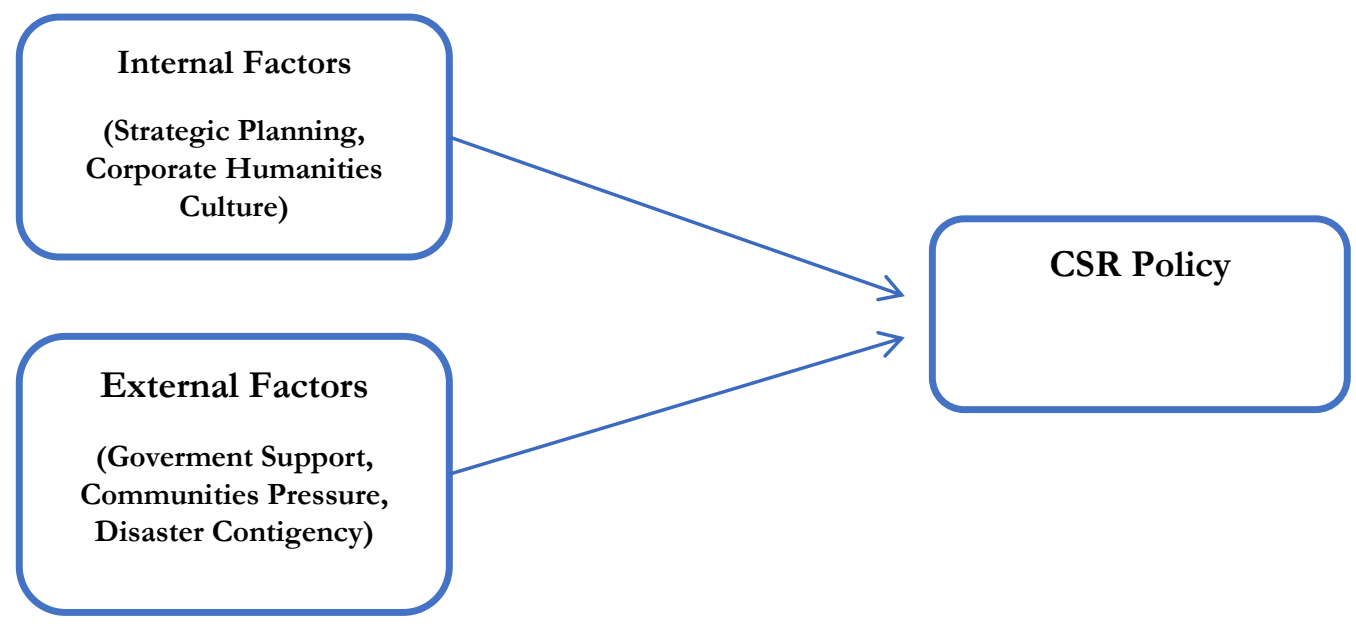

\section{Research Methods}

This research was conducted in the province of North Sumatra, Indonesia. This research is the second stage of research, The schedule from October to November 2020 as a follow-up to the CSR fund management model research conducted from June to August 2020. The number of companies that became respondents were 48 companies. Data collection was carried out using various online/online applications and the use of social media, namely Whatsapp, Facebook, Instagram and Twitter. The research questionnaire anad answered was distributed using the application Google form.

Table 3. Characteristics of the Sample are

\begin{tabular}{|c|c|}
\hline Business categorized & Companies sample \\
\hline Service & 5 \\
\hline Bank & 7 \\
\hline Trading & 10 \\
\hline Manufacturing & 8 \\
\hline Others & 18 \\
\hline Amount & 48 \\
\hline
\end{tabular}

Table 4. Variables and Indicators 
Disaster Contingency

Table 5. Testing of Internal and External Factor Indicators

\begin{tabular}{llll}
\hline item & $\begin{array}{l}\text { r calculate } \\
\text { value }\end{array}$ & $\begin{array}{l}\text { r-table df }=\mathrm{n}-2 \\
=30-2=28\end{array}$ & Description \\
\hline Strategic Planning & 0.619 & & Valid \\
Humanity Cultural & 0.716 & Valid \\
Government Support & 0.709 & $0.3510=0.352$ & Valid \\
Community pressure & 0.768 & & Valid \\
Disaster Contingencies & 0.677 & & Valid \\
\hline
\end{tabular}

Table 6. Reliability Test of Variables

\begin{tabular}{lll}
\hline Variabel & Cronbach's Alpha & N of Items \\
\hline Internal Factors & .734 & 6 \\
External Factor & .682 & 9 \\
& & \\
& & \\
CSR Policy & .711 & 3 \\
\hline
\end{tabular}

Table 7. The Results of the Normality Test of the Data with the Analysis of One-Sample Kolmogorov-Smirnov Test One-Sample Kolmogorov-Smirnov Test

\section{Unstandardized Residual}

\begin{tabular}{lll}
\hline $\mathrm{N}$ & 48 \\
Normal Parameters & & \\
& Mean & $0 \mathrm{E}-7$ \\
& Std. Deviation & 5.10955745
\end{tabular}




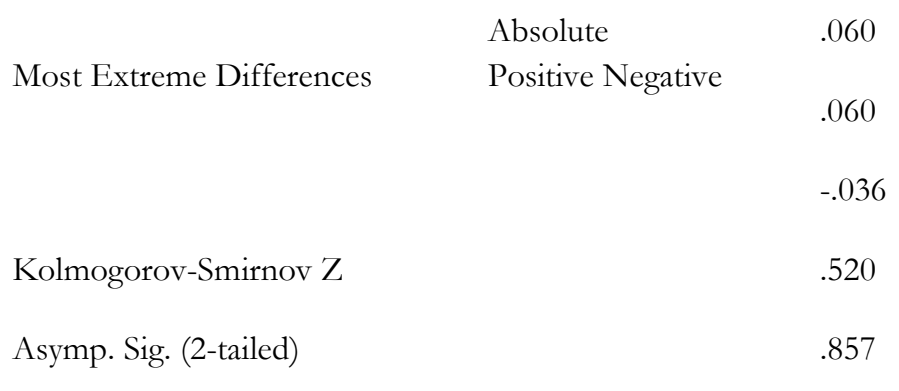

a. Test distribution is Normal.

b. Calculated from data.

The data analysis technique in this study is the multiple regression technique referring to Ghozali (2017). Multiple linear regression equation as follows:

CSR Policy $=a+b 1 \mathrm{INT}+\mathrm{b} 2 \mathrm{EKT}$ e

Description:

$$
\begin{array}{ll}
\mathrm{Y} & =\text { CSR Policy } \\
\text { INT } & =\text { Internal Factors } \\
\text { EKT } & =\text { External Factors } \\
\text { a } & =\text { constant } \\
\text { b1 } & =\text { regression coefficient } \\
\text { b2 } & =\text { regression coefficient } \\
\text { e }=\text { error } &
\end{array}
$$

Testing with test equipment $\mathrm{T}$ test in research in order to obtain test results whether there is an influence of the independent variables $\mathrm{X} 1$ and $\mathrm{X} 2$ individually/partially on the $\mathrm{Y}$ (bound) variable. The formula using the t-test is:

$$
t=\frac{r \sqrt{n-2}}{1-r^{2}}
$$

$$
\begin{aligned}
\mathrm{t} & =\mathrm{t} \text { count } \\
\mathrm{r} & =\text { regression coefficient } \\
\mathrm{n} & =\text { number of respondents }
\end{aligned}
$$

\section{Discussion}

By using the multiple regression analysis technique, it can be seen how much influence the independent variables, namely Internal and Factors External Factors have on the dependent variable, namely CSR Policy. The results of the calculation of multiple linear regression analysis using SPSS Version 20, can be seen as follows: 
Table 8. Summary of the Multiple Linear Regression Calculation Model Coefficients

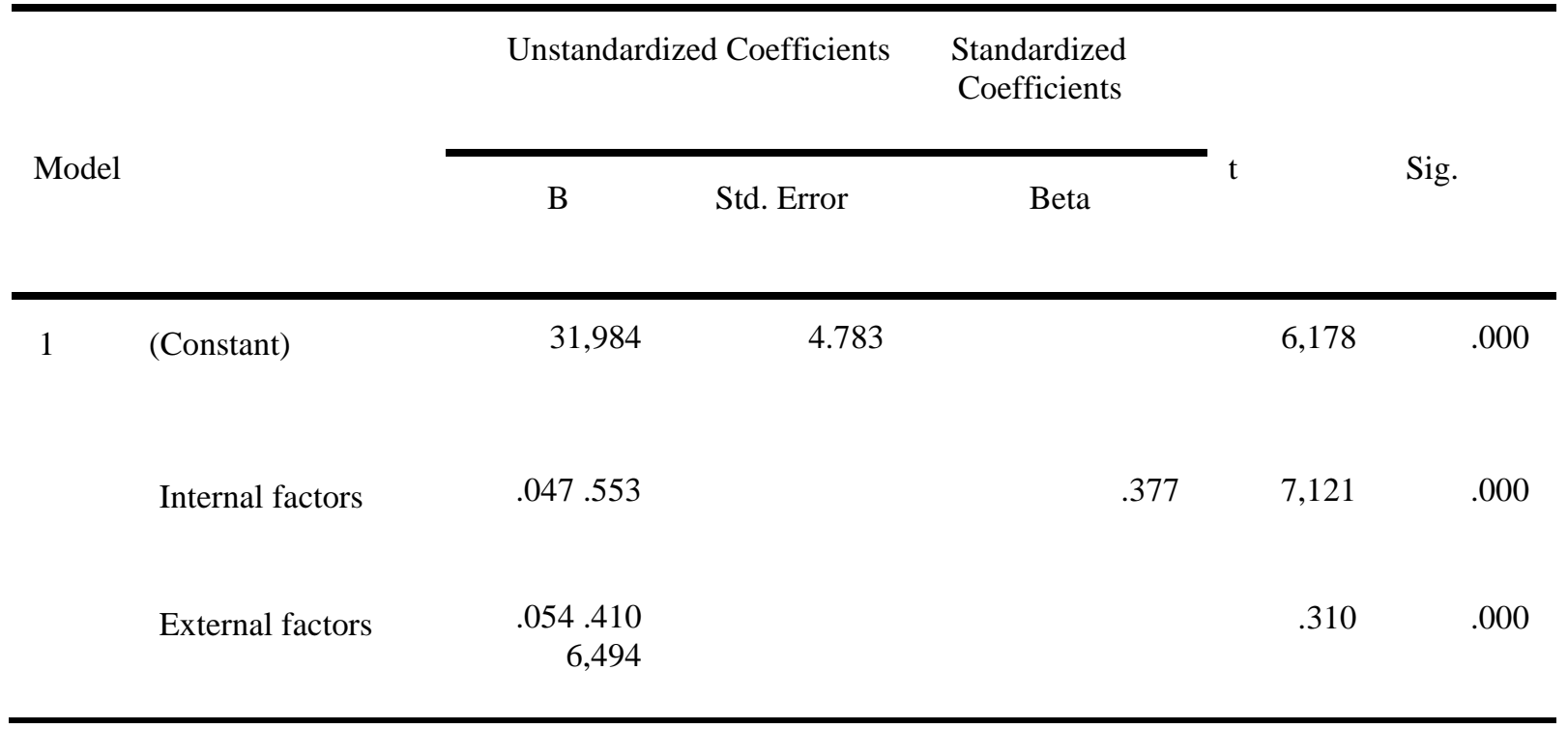

a. Dependent Variable: CSR Policy

Based on the results described above, the regression model formed is as follows:

\section{CSR Policy $=31.984+0.377 \mathrm{INT}+0.310 \mathrm{EKT}$}

Based on the equation obtained above, it can be interpreted as follows:

a. Constant As for

The constant value obtained at 31, 984 it means that by not being influenced by the independent variables, namely Internal Factors and External Factors, the CSR policy is 31,984.for the variable Internal factors obtained coefficient value of 0.377 , which means that if variable theis increased by 1 percent, the CSR policy will be increased by 0.377 points on condition that other independent variables remain valuable. The regression model above illustrates that if the Internal Support is more positive or better, then the CSR policy will increase.

Table 9. Proof of Partial Research

\begin{tabular}{lcccc}
\hline Hypothesis Tested & Table & tcount & Sig. & Conclusion \\
\hline $\begin{array}{c}\text { Ha1: there is a positive influence of } \\
\text { Internal factors on CSR policy }\end{array}$ & 1,983 & $8,126 \mathrm{Ha} 1$ & 0.000 & Accepted \\
$\begin{array}{c}\text { Ha2: there is a positive influence External } \\
\text { factors on CSR policy }\end{array}$ & 1,983 & 5,854 & 0.000 & Accepted \\
\hline
\end{tabular}


Table 10. Illustrates the Calculation of the Coefficient of Determination (R2) Model Summary

\begin{tabular}{ccccc}
\hline Model & $\mathrm{R}$ & R Square & Adjusted R Square & $\begin{array}{c}\text { Std. Error of } \\
\text { the Estimate }\end{array}$ \\
\hline & $.632^{\mathrm{a}}$ & .611 & .625 & 5.370 \\
\hline
\end{tabular}

a. Predictors: (Constant), INT and EKT

Based on the table above, the Adjusted RSquare value obtained is 0.625 . This means that the influence given by the independent variables INT and EKT on the dependent variable, namely CSR policy is $62.5 \%$, while the remaining $37.5 \%$ is influenced by other factors that are not discussed as variables in this study.

The results of this study prove that CSR (policiesCorporate Social Responsibility) originating from state-owned companies are mostly allocated for handling disasters such as the covid-19 pandemic. It is the obligation of every company to implement Corporate Social Responsibility (CSR) and include its budget for disaster management. As for the amount of the budget and the form of its activities, it is the right of each company. Since the spread of the COVID-19 pandemic in Indonesia, the Minister of State-Owned Enterprises has instructed every state-owned company to focus their CSR funds on handling COVID-19.

According to Rumambi (2018), there are several things that must be considered by every company, including BUMN companies in implementing CSR, namely, the existence of motivation in the form of willingness or compliance to carry out CSR programs or wanting to have a positive image in the community. This motivation encourages companies to conceptualize their CSR. The company prepares a strategic plan as a breakthrough in its CSR program. CSR programs such as social, community, sports and others. These programs can be carried out routinely or non-routinely in short-term and long-term programs. Fourth, to run the program, the company determines the funds for CSR activities. Funding for these activities needs to be budgeted based on their internal policies. Fifth, all CSR activities are reported to CSR activity reports, financial reports and annual reports. The results of this study are also in line with Azizul and Ade Fatma (2018) that government support and public pressure need attention. This study further strengthens the stakeholder theory which states that all parties involved must be considered by the company both internally and externally.

\section{Conclusion}

The results of hypothesis testing with multiple regression indicate that CSR policies are significantly influenced by both internal and external variables. The limitation of the study is that the sample is only one province and is recommended for a wider research area. The research implication is that the government should issue regulations to regulate CSR activities, especially those oriented to handling Covid 19 so that CSR can be more useful 


\section{References}

Ambani. 2018. Corporate Social Responsibility Policy. Commercial Bank of Dubai. https://www.cbd.ae/docs/librariesprovider2/default-document-library/csr-policydocument_10-12-2017_final.pdf.

Amran, Azlan; Devi, Susela Selvaraj. 2008. The impact of government and foreign affiliate influence on corporate social reporting: The case of Malaysia. Managerial Auditing Journal.

Azizul Kholis, 2012. Faktor Penentu Profesionalisme Dosen Akuntansi, Proseeding, Simposium Nasional penelitian dan Kebijakan Pendidikan, Departemen Pendidikan nasional RI, Jakarta

Azizul Kholis, Ade Fatma (2018) Determinants of corporate social performance (CSP) through corporate social responsibility (CSR) of foreign investment companies (PMA) in indonesia. International Journal of Economic Research

Azizul Kholis, Azhar Maksum. 2017. Analisis Tentang Pentingnya Tanggungjawab dan Akuntansi Sosial Perusahaan (Corporate Responsibilities and Social Accounting) Studi Kasus Empiris Di Kota Medan. Media Riset Akuntansi, Auditing \& Informasi

Azizul Kholis, Dedy Husrizalsyah, dkk 2020. The Research on the Model of SOE Corporate CSR Budget Management for Optimizing Disaster Management (Covid-19 Case Study in North Sumatra Province), Advances in Economics, Business and Management Research, volume 163 Proceedings of the International Conference on Strategic Issues of Economics, Business and, Education (ICoSIEBE 2020)

Badan Nasional Penanggulangan Bencana. 2012. Peraturan Kepala Banda Nasional Penanggulangan Bencana Nomor 1 Tahun 2012 tentang Pedoman Umum Desa/Kelurahan Tangguh Bencana. BNPB

Carroll, A. B. (1999). "Corporate social responsibility: evolution of a definitional construct". Business \& Society 38(3). pp. 268.

Catherine L. Mann 2020. Real and financial lenses to assess the economic consequences of COVID-19 A CEPR Press VoxEU.org eBook, CEPR Press. ISBN: 978-1-912179-282, Web: www.cepr.org

Fajar Nursaid, 2008, CSR Bidang Kesehatan dan Pendidikan Mengembangkan Sumber Daya Manusia, Cetakan pertama, Jakarta: Indonesia Business Link.

Frederick, W. C. 1994. From CSR to CSR2: The maturing of business-and-society thought. Working Paper No. 279, (Graduate School of Business, University of Pittsburgh).

Frederick, W. C. 2006. Corporation, be good! The story of corporate social responsibility. Indianapolis, IN: Dog Ear Publishing

Freeman \& Phillips, R. A. (2002). Stakeholder theory: A libertarian defense. Business Ethics Quarterly, 12(3), 331-349.

Friedman, 2007. Stakeholder Theory: Approach for bussisnes and social performance, Springer Publisher, Newyork, USA

Ghozali, I. (2017). Aplikasi Analisis Multivariate Dengan Program IBM SPSS 25.

Ghozali, Imam. 2017. Analisis statistic menggunakan aplikasi Wrap PLS (Edisi 8). Cetakan ke I, Semarang: Badan Penerbit Universitas Diponegoro.

Hall. 2015. Conceptual framework of Stake holder Theory: based on Friedman Model, Willey Inc, Publisher, USA

Heilman, hannah. 2012. Social and Humanity. mppnews, departement of management and philosopy. https://www.cbs.dk/files/cbs.dk/mpp_news_april_2012low.pdf.

Ismael Sinaga. 2020. https://www.sumutprov.go.id/artikel/artikel/pemprovsu-telahalokasikan-rp231-m-tangani-covid19. 
Keputusan Menteri Keuangan No.: 316/KMK.016/1994 tentang Pedoman Pembinaan Usaha Kecil dan Koperasi melalui Pemanfaatan Dana dari Bagian Laba Badan Usaha Milik Negara.

Keputusan Menteri Keuangan No.:1232/KMK.013/1989 tentang Pedoman Pembinaan Pengusaha Ekonomi Lemah dan Koperasi melalui Badan Usaha Milik Negara.

Keputusan Menteri Negara Pendayagunaan PMDN/Kepala Badan Pembina PMDN No.: Kep- 216/M-PPMDN/1999 tentang Program Kemitraan dan Bina Lingkungan PMDN

Kristesson, Beng, et. Al (2012), Humanity and Economic. mppnews, departement of management and philosopy. https://www.cbs.dk/files/cbs.dk/mpp_news_april_2012low.pdf

Madfre. 2018. CSR Policy. https://www.mapfre.com/media/shareholders/2015/corporatesocial-responsibility-policy.pdf.

Maulamin T. 2017. The Implementation of Corporate Social Responsibility (Csr) In Indonesia: A Case Study Approach. European Journal of Research in Social Sciences. Vol. 5 No. 1,2017

McWilliams A, Siegel D. 2001. Corporate social responsibility: a theory of the firm perspective. The Academy of Management Review 26: 117-127.

McWilliams A, Siegel DS, Wright PM. 2006. Corporate social responsibility: strategic implications. Journal of Management Studies 43: 1-18.

Miora, Buturoaga Cristina. 2016. CSR of State-Owned Companies in a European Developing Country - The Case of Romania. Journal of Organizational Management Studies.

Nosheen Rafi2 and Awais Nawaz Kalyar. 2012. Factors Affecting Corporate Social Responsibility: An Empirical Study, Systems Research and Behavioral Science Syst. Res. DOI: $10.1002 /$ sres.2134

Oe, H., \& Yamaoka, Y. (2020). How to enhance sustainability goals implementation in business behaviour: A lesson from discussions with Japanese small and medium-sized enterprises. Social Business, 10(3), 281-304.

P. Adámek. 2013. Roles of Government in Supporting Corporate Social Responsibility. 6th International Conference of Education, Research and Innovation. Silesian University in Opava, School of Business Administration in Karvina (CZECH REPUBLIC) ISBN: 978-84-616-3847-5, ISSN: 2340-1095

Peraturan Menteri Negara PMDN No.: Per-05/MBU/2007 tentang Program Kemitraan PMDN dengan Usaha Kecil dan Program Bina Lingkungan.

Permenkes No. 9 Tahun 2020 tentang mekanisme Pembatasan Sosial Berskala Besar (PSBB), Kementerian Kesehatan RI, Jakarta, akses pada www.kemenkes,go.id

Rumambi, H., Kaligis, S., Tangon, J., \& Marentek, S. (2018). The Implementation Model of Corporate Social Responsibility (CSR): An Indonesian Perspective. International Journal of Academic Research in Business and Social Sciences, 8(10), 761-773.

Sadostky, Hendrique. (1999). "Corporate Strategy and Interantional Environmental Policy". Journal of International Business Ethics, 29(4). pp. 819-820.

Semarang: Badan Penerbit Universitas Diponegoro

Susanto, A.B. (2007). "Corporate Social Responsibility". The Jakarta Consulting Group: Jakarta.

Sutton, J., and Tierney, K. 2006.Dissaster Preparedness: Concepts, Guidance and Research. University of Colorado. Colorado

Swiss Re, 2011. Natural Catastrophe and Man-Made Disaster in 2011: Historic Losses Surface from Record Earthquake and Floods. Report prepared for Swiss Reinsurance Company Ltd. (Publication No. sigma No2/2012), Economic Research and Consulting, Switzerland. 
Syahrial Ayub, Muh.Makhrus, dkk, 2017, Analisis Kesiapsiagaan Bencana Pada Guru Sekolah Dasar, 1Program Studi Pendidikan Fisika, Fakultas Keguruan dan Ilmu Pendidikan, Universitas Mataram, Mataram, Indonesia, Jurnal Penelitian Pendidikan IPA, 10.29303/jppipa. v6i1.281 pp. 52-56.

Takemoto, T., Oe, H., \& Yamaoka, Y. (2021). Sustainable Relationships within Organisations in an Age of Transition of Economy: Focus on Employees' Trust in Organisations. Economit Journal: Scientific Journal of Accountancy, Management and Finance, 1(2), 57-69.

Undang Undang Nomor 40 Tahun 2007 Tentang Perseroan Terbatas. Undang-Undang Nomor 19 Tahun 2003 tentang Badan Usaha Milik Negara.

Undang-Undang Nomor 20 Tahun 2008 tentang Usaha Mikro, Kecil dan Menengah.

Waddock, S. 2002. Leading corporate citizens: Vision, values, value added. New York: McGraw Hill.

Waddock, S. 2006. Hollow men and women at the helm... Hollow accounting ethics. Issues in Accounting Education, 20: 125-150. 35

World Health Organization, 2003. "Severe acute respiratory syndrome (SARS): Status of the outbreak and lessons for the immediate future", Geneva

World Health Organization, 2009. "Pandemi influenza preparedness and response: a WHO guidance document", Geneva.

World Health Organization, 2013. A Systematic Review of Public Health Emergency Operations Centres (EOC). World Health Organization.WHO/HSE/GCR/2014.1. Retrieved

World Health Organization, 2016. "WHO MERS-CoV Global Summary and risk assessment", Geneva. 